Seloka: Jurnal Pendidikan Bahasa dan Sastra Indonesia
$9(3)(2020): 230-238$
UNNES
https://journal.unnes.ac.id/sju/index.php/seloka

\title{
Readers' Reception of Satin Merah Detective Novel as a Literary Learning Material in Senior High School
}

\author{
Tegar Sulistya Sasongko ${ }^{\circledR}$, Teguh Supriyanto $^{2}$, Mukh Doyin $^{2}$ \\ ${ }^{1}$ Ahmad Yani Islamic Senior High School, Batang, Jawa Tengah, Indonesia \\ ${ }^{2}$ Universitas Negeri Semarang, Indonesia
}

\begin{tabular}{l}
\hline Article Info \\
\hline History Articles \\
Received: \\
Sebtember 2020 \\
Accepted: \\
Oktober 2020 \\
Published: \\
December 2020 \\
\hline Keywords: \\
eligibility, \\
novel, \\
reception \\
\hline
\end{tabular}

\begin{abstract}
Literary learning materials are one of the important components used by teachers in learning activities. Good learning materials can help students achieve learning goals. Sources of literature learning materials tend to focus on reference books from the government. Even though there are still many literary learning materials that can be used, one is novel. The research objective was to describe the teacher's response to Satin Merah's novel by Brahmanto Anindito and Rie Yanti as literary learning material at Senior High School. This research uses a pragmatic approach. The research is based on the reception of Indonesian language teachers at the Senior High School level on the feasibility of a novel based on the feasibility assessment of the BSNP in terms of content, language, and presentation. This study indicates that Satin Merah's novel's feasibility level is $82.5 \%$, which means that this novel is feasible and has a good reputation as literary learning material at Senior High School. The feasibility results are shown in terms of content feasibility of $84.2 \%$, language feasibility of $81.5 \%$, and presentation feasibility of $82 \%$. In terms of content, this novel develops self-potential, has creativity and depth of story, and develops readers' characters to love and preserve local culture. In terms of language, the language used is following Indonesian rules and according to the target audience. In terms of presentation, this novel pays attention to the building blocks and mostly develops characters and inspires readers.
\end{abstract}

\footnotetext{
Correspondence address:

Jl. Kyai Surgi, Dracik Kembang, Proyonanggan Selatan,

Batang, Jawa Tengah, 51216

p-ISSN 2301-6744

E-mail: sulistya_sasongko@yahoo.com
} 


\section{INTRODUCTION}

In essence, literary appreciation activities always lead to an emotional level. Until now, there are still many people who think that literary learning has not been successful by examining the lack of expected results or products (Doyin, 2015).

By reading literature, students are expected to hone their sensitivity and absorb the values that exist in literary work. Haniah (in Setyatmoko, 2017) literature serves as a tool for education. If associated with the message, almost all literary works are ethical means.

Literary appreciation learning has an essential role in shaping the character of students and fostering sensitivity. Language in literary works becomes a tool to create feelings. Language in literary works becomes a tool to make a special sense that contains an aesthetic value, apart from being a means of communication, conveying various information to the audience or readers (Istiqomah, 2014). Supriyanto (2014), when understanding literary works, the first step is to understand language first.

Teaching materials are essential learning tools and resources and can help students develop knowledge, skills, and personalities, both at school and outside school (Hadi, 2015). The problem that teachers often face so far is choosing or determining teaching materials, especially novels. Novels, as imagination, always offer various human and human problems between life and life (Nurgiyantoro in Christiani, 2015). The fact is that the novel used is only fixated on books that have become a government reference. For example, Harimau! Harimau! by Mochtar Lubis, "Bumi Manusia" by Pramoedya Ananta Toer, and "Ronggeng Dukuh Paruk" by Ahmad Tohari.

From the description of the obstacles above, the middle way that can be taken to solve them is by focusing on the selection of literature learning materials. Novels can be used as guides in life's problems, including popular novels, including detective novels. A novel can be used as a material to study real human experience.
Various human traits and life descriptions are all recorded in a novel (Khusnin, 2012).

Based on the description above, it is illustrated that Satin Merah's novel has advantages, can penetrate a wider audience and can position itself as a novel that is different in terms of its storyline, the appointment of a unique character, namely, a student and writer and the preservation of regional culture. This makes researchers want to see how much the feasibility level of Satin Merah detective novel by Brahmanto Anindito and Rie Yanti as literature learning material at Senior High School.

In this study, the researcher limited the teacher's reception to the feasibility of Satin Merah detective novel by Brahmanto Anindito and Rie Yanti in terms of content, language, and presentation appropriateness. To overcome this research problem, the theory used was structuralism, literary reception, and novel feasibility according to BSNP.

Nurgiyantoro (in Sapdiani 2018), the literary work of fiction, according to structuralism, is a totality that is built coherently by various building elements. Structural analysis is not sufficient to do with data or something else, but what is more important is to show how the relationship between these elements is (Nurgiyantoro in Nugroho, 2014).

Teeuw (1984) argues that structural analysis is a stage in literary research that is difficult to avoid because such (structural) analysis only allows optimal understanding. Lévi-Strauss (in Lixian, 2013) the goal of structuralism is to understand concrete reality with sensing and intellect, quality and quantity, concrete and abstract, and so on cannot be separated.

Satoto (in Dewi, 2019) states that a structuralism approach is an intrinsic approach, namely talking about the work on the elements that build literary works from within. Semi (in Hidayat, 2017), the inner structure (intrinsic) is the elements that make up the literary work such as characterization or characterization of the theme, plot, narrative center, setting, and language style. 
Pradopo (in Intan, 2019), reception aesthetics is a pragmatic critical research method, namely literary research that emphasizes readers' role as greeters and audiences of literary works. In line with this opinion, Jauss (in Sungkowati, 2011), literary reception means the reader's response to literary works. Wahyudi (in Gumono, 2017) states that the pragmatic approach is a literary study approach that focuses on studying the reader's role. According to Pradopo (2007), what is meant by reception is the science of beauty, which is based on readers' responses to literary works. Fokkema (in Sukiman, 2013) states that the relationship between literary works and readers has aesthetic implications because literary texts will become an aesthetic object after they are read and concretized by readers.

To analyze a novel's feasibility, the researcher referred to the Nontext Textbook Assessment Guide for the National Education Standards Agency (2018). The purpose of this study is to describe the teacher's response to Satin Merah's novel by Brahmanto Anindito and Rie Yanti as literary learning materials at Senior High School.

Theoretically, this research is expected to contribute thoughts in terms of selecting and determining literary learning materials. Practically, this study's results can be used as alternative teaching material in teaching literature in Senior High School.

\section{METHODS}

The research design was designed using a pragmatic approach, meaning that data analysis was based on people's responses to popular novels' feasibility, especially the Satin Merah detective novel, as literary learning material. What is meant by community response is the response from the school community, namely Indonesian language teachers.

The data in this study are qualitative in the form of non-numeric words/numbers obtained from Indonesian teachers' responses to the feasibility of the Satin Merah detective novel by Brahmanto Anindito and Rie Yanti. This research's data source is the Indonesian language teacher at a Public/Private Senior High School in Batang Regency.

In this study, data collection techniques are communication techniques, namely how to collect data through contact or personal relationships between data collectors and data sources (Margono, 2010). In this study, researchers used indirect communication techniques in the form of a questionnaire (questionnaire system).

The steps taken in collecting and analyzing data are collecting data from a questionnaire that has been given to respondents (Indonesian language teachers), providing a sign to the Indonesian teacher's questionnaire response to the detective Satin Merah novel written by Brahmanto Anindito and Rie Yanti, analyzing the language teacher's reception Indonesia regarding the feasibility of Satin Merah novel by Brahmanto Anindito and Rie Yanti, determines the feasibility of the novel according to the teacher's reception of Satin Merah novel by Brahmanto Anindito and Rie Yanti in terms of content, language, and presentation as literature learning material at Senior High School, and concludes the results of the analysis and the feasibility of Satin Merah novel by Brahmanto Anindito and Rie Yanti based on the eligibility criteria from BSNP.

\section{RESULTS AND DISCUSSION}

The Indonesian language teacher's response to Satin Merah detective novel, written by Brahmanto Anindito and Rie Yanti, was used as literature learning material in Senior High School.

\section{Content/Material Feasibility \\ The content supports the development of the potential of students}

There are ten answers in a questionnaire from Indonesian Senior High School teachers in the Batang Regency regarding the feasibility of content that supports students' potential development. The data obtained shows that five teachers gave a score of seven. One of them 
stated that in Satin Merah's novel, most of the content supported students' development to develop their potential/achievements, especially in writing. Unfortunately, there are characteristics of the main character that are not following students' development, namely doing what to get something. On a score of eight, one teacher stated that most of the contents supported students' development in Satin Merah's novel, especially fostering a sense of preserving local culture. It also encouraged students to like writing. At a value of nine, four teachers stated that Satin Merah's novel supports the development of students in terms of content. According to one teacher, Satin Merah's novel is very suitable to encourage students' development to excel, and this novel provides knowledge about how to write and become a great writer.

The content does not conflict with the applicable regulations in Indonesia

The content indicator does not conflict with applicable regulations in Indonesia (pornography, human rights, copyright, and other rules) shows that the results of the reception/responses of Indonesian high school teachers in Batang Regency are three teachers, giving a score of eight and stating that Satin Merah novel some of the contents do not contradict the applicable regulations in Indonesia even though the story is presented with a murder story because this novel is a detective novel genre. At a score of nine, three teachers stated that this novel did not contradict any regulations or laws in Indonesia (pornography, human rights, copyright, and other rules). However, there was one scene where almost raped the main character. The author described the scene well, and without vulgarity, so it doesn't matter. Four teachers are giving a score of ten. According to one of the teachers, Satin Merah's novel story does not contradict Indonesia's laws, especially pornography, human rights, and copyright laws.

The content does not cause racial problems and does not discriminate
In the content indicator, it does not cause racial or discriminatory behavior. It is obtained data that five out of ten teachers gave a score of ten. They argue that the content/story of Satin Merah's novel does not cause racial problems or discrimination. For example, in the story, it does not show a job that is only done by men but can also be done by a woman only. Five teachers gave a score of nine because the coverage of the story material in Satin Merah's novel did not cause racial problems (ethnicity, religion, race, and intergroup) and discrimination against the main character and other characters in the story.

\section{The content has a high degree of depth and creativity}

The content feasibility of the content indicator has high depth and creativity. Based on the data obtained, six teachers gave a score of six in terms of content depth and creativity. One of them argues that Satin Merah's novel has sufficient depth and creativity in its content. This is shown by the author, who tells the life of a student today who is modern-minded, broad, and follows technological developments combined with regional culture, especially local languages that are considered "strange" among today's teenagers. At the score of seven three teachers gave the score. They also argue that Satin Merah's novel has sufficient depth and creativity in its content. This can see this from the story model that combines regional language development with current children's development, especially students who prefer contemporary language. For a score of eight, three teachers gave the score, one of the teachers thought this novel had enough depth and creativity in the story's content. This can be seen from the presentation of stories depicting the lives of high school adolescents who are introduced to one of the regional languages, namely Sundanese, which is wrapped in incidents of killings that are rarely raised for students. This has become a special affection for the presentation of Satin Merah's novel. For the last assessment, as many as four teachers gave a score of nine because, according to them, Satin Merah's novel had depth and creativity in the 
content, reflected this in the plot, which was presented coherently, and neat flashbacks, especially since this novel is a detective/mystery genre more different.

\section{The contents build the character of the nation}

In the content indicator to build national character, data was obtained that two teachers gave a score of six. One of them argues that most of the contents of the story contain values that readers can take, ranging from cultural values, educational values, and knowledge values. However, in terms of presentation, the writer presents a conflict that slightly hits the national character described by the main character as having a negative character. Three teachers gave a score of seven. One of them said that the characters in the story mostly describe their love for cultural values, one of which is the local language. This novel also provides knowledge about writing. The author also provides a clear picture of the current development of regional languages. Then two teachers gave the score eight. From their assessment, Satin Merah's novel mostly builds the nation's character, especially preserving one's own culture, apart from the pluses and minuses of the characters presented. In the next assessment, 2 Indonesian language teachers gave a score of nine. One of them argues that Satin Merah's novel's essence is very good, especially for current students. After all, this novel makes readers aware of the importance of loving the nation's culture, knowing the current cultural developments, especially regional languages, apart from presenting stories about murder because this novel is a mystery genre. In the last assessment, there was one teacher who gave a score of ten. In his opinion, when viewed from the story, this novel clearly describes the author's purpose, who wants to tell the development of the nation's culture, especially regional literature, which is starting to erode the times. Not only that, but the author also introduces Sundanese writers and tries to invite readers to love the nation's culture more, especially regional languages.
According to the data obtained from five indicators regarding the appropriateness of the Satin Merah novel's contents, the average calculation of receptions for ten teachers has been done. The average percentage for content eligibility based on the teacher's reception/response is $84.2 \%$, so the content feasibility level is categorized as good. The average is obtained from five content feasibility assessment indicators. The first assessment indicator, namely the content, supports students' potential, getting a feasibility percentage of $79 \%$ can categorize as deserving of a good predicate. The second assessment indicator is that the content does not contradict the applicable regulations in Indonesia, getting an eligibility percentage of $91 \%$, categorizing as very good. In the third assessment indicator, namely, the content does not cause racial problems. There is no discrimination. Getting can categorize an eligibility percentage of $95 \%$ as very good predicated. In the fourth assessment indicator, namely, the content has a high depth and creativity, getting a feasibility percentage of $79 \%$ can be said to categorize as deserving of a good predicate. In the last feasibility assessment indicator, which is the fifth indicator, the content of building a high national character gets an eligibility percentage of $77 \%$. In general, according to the teacher's response in terms of the eligibility of the content, the feasibility of Satin Merah's novel is categorized as having a good predicate.

\section{Language Eligibility}

The language used is ethical, aesthetic, communicative, and appropriate to the target audience

The instrument of language appropriateness, especially the language indicators used ethically, aesthetically, communicatively, and according to the target, reader shows that two teachers give a score of seven and state that the language used in Satin Merah's novel is mostly ethical, aesthetic, communicative, and appropriate. With the target audience. According to the reason, the language used must be aesthetic, 
communicative, and following the target audience, especially students, because this novel tells of a student who wants to be recognized for his existence. Still, some words or language are less ethical (polite) when the characters express annoyance. The next assessment by five teachers gave a score of eight; according to him, the language used in Satin Merah's novel was easy to understand even though there were inserts in Sundanese and this novel. The language was quite aesthetically pleasing and suitable for target readers, especially high school students. It's just that there are some unethical words used from Indonesian itself and Sundanese. In the last assessment, three teachers gave a score of nine. From their evaluation, the language used is not a problem and is suitable for the students. However, the words "Blegug" and "Borokokok" can be accepted or not for students.

\section{Language according to the rules and standard terms}

The language feasibility instrument, especially the language indicator, follows the rules, and the standard term shows that ten teachers give various scores for language feasibility. For six points, there is one teacher who gives a grade. Most of the languages used in Satin Merah's novel are used according to standard Indonesian rules, but many nonstandard languages are used in conversations between characters. In the next assessment, two teachers gave a score of seven. According to them, the language used in this novel has paid attention to EYD from Indonesian and the use of foreign terms. One teacher who gave a score of eight argued that the language used was mostly following Indonesian rules, but some words were not standard other than in conversation. In the last assessment, six teachers gave the score nine. One of them assumes that the language used in Satin Merah's novel is following the rules of writing Indonesian and does not use slang (as I wish).

According to the two indicators regarding the feasibility of Satin Merah novel, especially in the language feasibility instrument, the researcher obtained an average percentage value from the reception of the ten teachers that had been done, indicating that the average percentage for language feasibility based on the teacher's reception/response was $81.5 \%$ so can say that the feasibility level of the language is categorized as having a good predicate. The average is obtained from two indicators of language feasibility assessment, according to BSNP. The first assessment indicator is the language used ethically, aesthetically, and communicatively. According to the target audience, getting an eligibility percentage of $81 \%$ can be categorized as deserving of a good predicate. The second indicator, namely the language according to the rules, and the standard terms get a feasibility percentage of $82 \%$, can say that the category is worthy of being good. In general, it can be concluded that the feasibility of Satin Merah's novel, according to the teacher's response in terms of the feasibility of the language, is categorized as having a good predicate according to the feasibility assessment of the BSNP.

\section{Serving Feasibility}

\section{The story presentation is done by paying attention to the intrinsic elements}

The presentation feasibility instrument, especially in the story presentation indicator, is carried out by paying attention to the intrinsic elements, it is obtained data that one teacher gives a six value, according to him, the presentation of Satin Merah's novel has actually paid attention to the building blocks, but unfortunately, this novel only emphasizes the plot aspect. For the value of seven, only one teacher gave a grade. According to him, the intrinsic element built into Satin Merah's novel is good. It's just that in terms of the plot, it is quite confusing for the reader. According to him, the value of eight was only given by one teacher, the presentation of Satin Merah's novel was good in terms of its intrinsic element. Still, in the plot part, it was not given enough attention because it was not neat in its storytelling. Furthermore, seven teachers gave the score nine. According to him, Satin Merah's 
novel's presentation contains all the intrinsic elements of literary works.

\section{Presenting stories develops character, intellectual, emotional, social and spiritual skills}

The presentation feasibility instrument, especially the story presentation indicator, develops character, intellectual, emotional, social, and spiritual skills. It shows that one teacher gives a score of six. According to him, in terms of story presentation, most of them have paid attention to this but seen from the main character, the character development is not good. There are several negative characteristics of the character, one of which is doing various ways to achieve his goals. Three teachers gave the grade seven. According to one of them, the story's presentation in Satin Merah's novel mostly includes these elements. Still, in character development, the characters are not good, especially in the main character. In the next assessment, there was one teacher who gave a score of eight. According to him, Satin Merah's novel presentation was able to develop one's character for achievement and develop one's talents, one of which was to become a writer. From an emotional and spiritual perspective, it was portrayed poorly by the author, especially in character representation. For the value of nine, four teachers give value, according to one of them, if seen from the presentation of the story, which is classified as a mystery/detective novel, this novel has good character, intellectual, emotional, social, and spiritual skills from both positive and negative aspects. Finally, there is one teacher who gives a ten. According to him, the presentation of Satin Merah's novel is packaged in such a way as to make the story pattern alive, develop the character of the character's character, develop intellectual skills from the science of writing, develop emotional, social, and spiritual behavior of the characters.

Presentation of innovative, creative, and inspirational stories
The presentation instrument's appropriateness, especially in presenting innovative, creative, and inspirational stories, obtained data that four teachers gave a value of seven. Innovative and creative, but a little inspiring because the depiction of the main character, who is not given enough attention because of being a murderer, is different if the main character uncovers the mystery of the murder. In the next assessment, there was one teacher who gave a score of eight. According to him, the pattern of presenting Satin Merah's novel story is quite creative when viewed from the plot. It is quite inspirational for readers, especially to become a writer, regardless of what the main character is doing. Finally, five teachers gave grade nine. According to one of them, the story raised was relatively new, with an unusual theme for students who could inspire and provide a writer's picture.

According to the three indicators regarding the feasibility of Satin Merah novel, especially in the presentation feasibility instrument, the researcher obtained an average calculation that the average percentage for the feasibility of presentation based on the teacher's reception/response was $82 \%$, so the level of language feasibility is categorized as deserving of a good predicate. The average is obtained from three indicators of assessment feasibility of presentation, according to BSNP. The first assessment indicator is that the story's presentation is done by paying attention to the intrinsic element. Getting a percentage of the feasibility of $84 \%$ can be categorized as deserving of a good predicate. The second indicator, which is the story's presentation, develops character, intellectual, emotional, social, and spiritual skills. Getting an eligibility percentage of $81 \%$ can be categorized as deserving of a good predicate. The last assessment indicator, namely the third indicator, the presentation of innovative, creative, and inspirational stories, gets an eligibility percentage of $81 \%$ that the category deserves a good predicate. In general, the feasibility of Satin Merah novel, according to the teacher's response in terms of presentation feasibility, is in 
the proper category, with a good predicate, according to the feasibility assessment of BSNP.

\section{CONCLUSION}

Based on the description of the data and discussion, can be concluded that in the analysis of the feasibility of Satin Merah's novel in terms of content feasibility, the feasibility level of Satin Merah novel is $84.2 \%$, and it is suitable as a literature learning material in Senior High School. Feasibility in terms of language eligibility gets $81.5 \%$ and categorized as suitable as literature learning material in Senior High School. In terms of presentation feasibility, the feasibility level is $82 \%$, meaning that this novel is worthy of being used as a literature learning material in high school in terms of presentation. The average feasibility percentage of Satin Merah's novel by Brahmanto Anindito and Rie Yanti from ten teachers' reception was $82.5 \%$. This novel is suitable as a literature learning material in Senior High School based on the feasibility assessment of BSNP.

\section{REFERENCES}

BSNP. (2018). Instrumen Penilaian Buku Pengayaan Kepribadian. Jakarta: Pusat Kurikulum dan Perbukuan Badan Penelitian dan Pengembangan Kementrian Pendidikan dan Kebudayaan.

Cristiani, R.F., Rustono., \& Agus N. (2015). "Citra Wanita, Pengungkapannya, dan Nilai Kehidupan dalam Kumpulan Novel Seri Detektif Handaka Karya Suprapto Brata". Seloka, 4 (2): 58-64.

Dewi, T.U., Indah, D.N.S., \& Fanny, R. (2019). "Kritik Novel Assalamualaikum, Beijing! Karya Asma Nadia : Pendekatan Struktural”. Jurnal Imajeri, 1 (2): 91-100.

Doyin, M. (2015). "Developing Poetry Teaching Material in Elementary School". The Journal of Educational Development, 3 (1): 21-29.

Fahmi, R.N., Amir, F., Herman J.W. (2014). "Analisis Tokoh Utama dan Nilai
Pendidikan Karakter dalam Novel Anak Sejuta Bintang Karya Akmal Nasery Basral". Basastra, 2 (3): 1-11.

Gumono, A.T. (2017). "Analisis Film Denias dengan Pendekatan Pragmatik". A Journal Of Language, Literature, Culture, And Education, 13 (1): 69-78.

Hadi, D.C. (2015). "Pengembangan Bahan Ajar Memahami Hikayat Bermuatan NilaiNilai Moral untuk Peserta Didik SMA/MA". Seloka, 4 (1): 1-8.

Hidayat, A.D., \& Supriyanto, T. (2017). "Paradoks dan Hiperbola dalam Kumpulan Cerita Koala Kumal Karya Raditya Dika". Seloka, 6 (1): 34-43.

Intan, T. (2019). "Resepsi Remaja Perempuan Pembaca Novel Populer". Metahumaniora, 9 (2): 157-167.

Istiqomah, N., \& Doyin, M. (2014). "Sikap Hidup Orang Jawa dalam Novel OrangOrang Proyek karya Ahmad Tohari". Jurnal Sastra Indonesia, 3 (1): 1-9.

Khusnin, M. (2012). "Gaya Bahasa Novel AyatAyat Cinta Karya Habiburrahman E1 Shirazy dan Implementasinya terhadap Pengajaran Sastra di SMA". Seloka, 1 (1): 45-53.

Lixian, X. (2013). "Analisis Struktural Novel Hong Loo Meng". Humaniora, 25 (2): 163174.

Nugroho, A. (2014). "Analisis Struktural Novel Berlayar ke Surga Karya Ramadha Tsulatsi Hajar dan Implementasinya sebagai Bahan Pembelajaran di SMA". Jurnal Surya Bahtera, 2 (13).

Margono. (2010). Metodologi Penelitian Pendidikan. Jakarta: PT Rineka Cipta.

Pradopo, R.D. (2007). Beberapa Teori Sastra, Metode Kritik, dan Penerapannya. Yogyakarta: Pustaka Pelajar.

Sapdiani, R., Imas, M., Pipin P., \& Dida F. (2018). "Analisis Struktural dan Nilai Moral dalam Cerpen "Kembang Gunung Kapur" Karya Hasta Indriyana". Parole , 1 (2): 101-114.

Setyatmoko, P.F., \& Supriyanto, T. (2017). "Penyimpangan Sosial dalam Novel 
Neraka Dunia Karya Nur Sutan Iskandar". Seloka, 6 (3): 307-313.

Sukiman, U. (2010). "Resepsi Sastra Novel Sarah Karya Abbas Mahfud Al-Aqqad". Adabiyyat, XII (1): 208-228.

Sungkowati, Y. (2014). "Pengaruh Cerita Detektif Tradisional Barat terhadap
Novel Indonesia Mencari Sarang Angin dan Kremil Karya Suprapto Brata". Metasastra, 7 (1): 109-122.

Supriyanto, Teguh. (2014). Kajian Stilistika dalam Prosa. Yogyakarta: Elmatera Publishing.

Teeuw. (1984). Sastra dan Ilmu Sastra Pengantar Teori Sastra. Bandung: Pustaka Jaya. 